\title{
DISCRIMINATION AND THE COMMERCE CLAUSE: APPLICATION OF STATE CIVIL RIGHTS ACTS IN INTERSTATE AND FOREIGN COMMERCE*
}

Despite its originally exclusive interpretation, ${ }^{1}$ the Commerce Clause 2 has not entirely prevented the states from exercising regulation over the interstate and foreign commerce which passes within their boundaries. ${ }^{3}$ In the absence of conflicting or superseding federal enactment, there is said to exist in the state a residuum of power to legislate in this regard, ${ }^{5}$ except

* Bob-Lo Excursion Company v. Michigan, 333 U. S. 28 (1948).

1. "[The power of] a state [to]regulate commerce with foreign nations and among the states . . . cannot be admitted". Gibbon v. Ogden, 9 Wheat. 1, 201 (U. S. 1824). "... the power to regulate foreign commerce is necessarily exclusive [to the federal government]". Id. at 228 .

2. U. S. Coxst. Art. I, $\$$, cl. S. "The Congress shall have the power to regulate commerce with foreign nations and among the several states. ..."

3. Professor Willis observes that "... in the last few decades, the Supreme Court has been permitting the states to exercise many forms of social control which indireetly or incidentally affect interstate commerce, when the states in doing so are undertaling to protect some general social interests of the people of the state, even when the interstate commerce is a matter of national concern and the federal government's rower is regarded as exclusive." Wilis on Constrturional Law, 328. See illustrations, id. 323331 ; footnotes 16 and 17, Morgan v. Virginia, 328 U. S. 373 (1946).

4. Federal action has been held to supersede state legislation only where the repugnance is considered to be so direct and positive that the two acts cannot be reconciled. Sinnot v. Davenport, 22 How. 227, 243 (U. S. 1859); Mlissouri, K. \& T. Ky. Co. v. Haber, 169 U. S. 613, 623, 624 (1S9S); Savage v. Jones, 225 U. S. 501,533 (1912); Mintz v. Baldwin, 289 U. S. 346,350 (1933); Kelley v. Washington, 302 U. S. 1, 9 (1937) ; Mraurer v. Hamilton, 309 U. S. 59 (1940) ; Parker v. Brown, 317 U. S. 341 (1943). But cf., Bethlehem Steel Corp. v. N.I.S.L.R.B., 330 U. S. 767 (1940); Cloverleaf Butter Co. v. Patterson, 315 U. S. 148 (1942).

5. The Commerce Clause does not preclude reasonable exercise of state authority as to those matters of interstate and foreign commerce which are local in character. Cooley $v$. Board of Wardens, 12 How. 298 (U. S. 1851). See Southern Pacific Ry. Co. v. Arizons, 325 U. S. 761,766 (1945).

The allocation of power between the states and the federal government has been held to be predicated upon the implications of the commerce clause itself. Brown v. Maryland, 12 Wheat. 419, 447 (U. S. 1827) ; Minnesota Rate Cases, 230 U. S. 352, 399-400 (1913); Baldwin v. Seelig, 294 U. S. 511, 522 (1935) ; South Carolina Hwy. Dept. v. Barnwell Bros. Inc., 303 U. S. 177, 185 (1938). It has also been based on the presumed intention of Congress, where Congress has not spoken. Silence of Congress has been held to preclude state regulation. Welton v. Missouri, 91 U. S. 275, 282 (1875) ; Brown v. Houston, 114 U. S. 622, 631 (1885) ; Brennan v. Titusville, 153 U. S. 239, 302 (1894). But cf., Graves v. New York, 306 U. S. 466,479 (1939). See generally Bikle, The Silence of Congress, 41 HARv. L. REv. 200 (1927). 
where the legislation would burden commerce by discriminating against out-of-state commerce ${ }^{6}$ or disturbing national uniformity. ${ }^{7}$

Such state legislation in the civil rights field was examined in Bob-Lo Excursion Company v. Michigan. ${ }^{8}$ Appellant, a Michigan corporation which maintained recreational facilities on Bois Blanc, an island located in the Canadian territorial waters of the Detroit River, denied passage to the island and the use of its facilities to a Negro in accord with a standing company policy of racial exclusion. ${ }^{9}$ Perhaps because there was doubt as to the applicability of the anti-discriminatory provisions of the Interstate Commerce Act ${ }^{10}$ in the instant context, ${ }^{11}$ criminal proceedings were instituted against the excursion company under the Michigan Civil Rights Act, ${ }^{12}$ which clearly prohibits racial and religious discrimination. Appellant demurred and challenged the constitutionality of the statute as enforced, citing the fact that Bois Blanc is politically a part of the Province of Ontario and asserting amenability to federal regulation only.

6. State regulation of interstate commerce has been enjoined where its purpose or effect has been to gain for those within the state an advantage at the expense of those without. Foster Fountain Packing Co. v. Haydel, 278 U. S. 1 (1928) (statute discriminating against out-of-state packer); Baldwin v. Seelig, 294 U. S. 511 (1935) (statute prescribing minimum price on out-of-state milk). But cf. Geer v. Connecticut, 161 U. S. 519 (1896) (statute prohibiting killing game for export upheld); South Carolina Hwy. Dept. v. Barnwell Bros., 303 U. S. 177, 187 (1938) (statute discriminating against out-of-state motor traffic).

7. "Whatever subjects of this power are in their nature national ... may justly be said . . . to require exclusive legislation by Congress". Cooley v. Board of Wardens, 12 How. 298, 319 (U. S. 1851) ; Minnesota Rate Cases, 230 U. S. 352, 399, 400 (1913); Edwards v. California, 314 U. S. 160, 176 (1941); Southern Pacific Ry. Co. v. Arizona, 325 U. S. 761 (1945).

See generally, Dowling, Interstate Commerce and State Power, 27 VA. L. REv. 1 (1940); Dowling, Interstate Commerce and State Power-Revised Version, 47 Cor. L. REv. 547 (1947).

8. 333 U. S. 28 (1948). The opinion below is reported at 317 Mich. 686,27 N. W.2d 139 (1947).

9. The policy of excluding Negroes from the use of these facilities had been in effect for twenty-one years prior to 1945 . The assistant general manager testified that the policy was designed to insure the continued success of the enterprise. Record of Trial, 10, 11.

10. 24 Stat. 380 (1887), as amended, 41 Stat. 479 (1920), 54 Stat. 899 (1940), 49 U. S. C. $\S 3(1)$ (1946), extended to carriers by water, 49 Stat. 1518 (1936), 46 U. S. C. $\S 815$ (1946) ; 54 Stat. 934 (1940), 49 U. S. C. $\$ 905$ (1946); and air, 52 Stat. 973 (1938), 49 U. S. C. 484 (1946).

11. The Interstate Commerce Act excludes from the purview of its opcration transportation by small craft of not more than one hundred tons carrying capacity or not more than one hundred indicated horsepower, and also ferries. 60 Stat. 1097 (1946), 49 U. S. C. $\$ 903(\mathrm{~g})(2)$ (1946). The record does not disclose the size of the excursion boat involved here, and whether or not the ressel would be called a ferry is open to doubt.

12. Mrch. Penal. Code $\$ \$ 146-148$, Mrce. Comp. Laws $\$ \$ 17115-146$ to $17115-148$ (Supp. 1940), Mich. Stat. ANN. $\$ \$ 28.343-28.346$ (Cum. Supp. 1946). These sections of the Penal Code require provision of full and equal facilities to all citizens in places of public accommodation, including public conveyances on water. 
- Two fundamentally divergent approaches to the decision were offered by the facts. The first, followed by the Court majority, turned upon the peculiarly local character of the commerce involved: since both legal and physical barriers prevented intercourse between the appellant's patrons on Bois Blanc and Canadians, the island was in effect an amusement adjunct of Detroit. ${ }^{13}$ On this showing, the Court held that the merely technical foreign aspect of the Bob-Lo excursions should not operate to preclude state regulation. ${ }^{14}$ In effect the commerce was held to be wholly intrastate for this purpose, and the issue under the Commerce Clause deftly avoided.

On the other hand, Mr. Justice Douglas, concurring, and Mr. Justice Jackson, dissenting, concluded that the commerce was indeed foreign, but arrived at opposite conclusions as to the permissibility of state regulation. Mr. Justice Douglas reasoned that there was here no superseding or presently conflicting statute. The Interstate Commerce Act was apparently not in issue ${ }^{15}$ - and even if it had been, it could not have conflicted for it also prohibits exclusion; Canadian law, with which the Bob-Lo excursions might be held concerned, also indicates clear opposition to racial discrimination; ${ }^{16}$ and the states do not and cannot require racial exclusion under the Fourteenth Amendment. ${ }^{17}$ Finding no possibility of conflict in regulation, and noting the enforcement of the common law rule that common carriers must provide equal service to all ${ }^{18}$ as an indication of national policy, Mr. Justice Douglas concluded that the statute constituted no undue burden on foreign commerce. ${ }^{19} \mathrm{Mr}$. Justice Jackson, however, considered the tech-

13. Although passengers were subject to customs and immigration inspection, transportation to the Canadan mainland was forbidden by Canadian authorities. No intermediate stops were made, and patrons were returned to Detroit the same day. Record of Trial, s.

14. Bob-Lo Excursion Co. v. Michigan, 333 U. S. 28, 29-40 (1948).

15. See note 11 supra.

16. See Statutes of Ontario, Canada, \& Gro. VI c. 51 (1944).

Further indicia of a sympathetic Canadian policy appear in RE Drummond Wren, [1945] O.R. 778, where the court, in ruling that racial covenants are contrary to current public policy, relied in part on Canada's adherence to the United Nations Charter, Art. 55c, 56: “... the United Nations shall promote universal respect for and observance of human rights and fundamental freedoms for all without distinction as to race... [and] all members pledge themselves to take joint and separate action [for that purpose]."

17. "No state shall ... . deny to any person within its jurisdiction the equal protection of its laws." U. S. Const., Art. XIV, cl. 1. Yick Wo v. Hoplins, 118 U. S. 356 (1886); Missouri ex rel. Gaines v. Canada, 305 U. S. 337, 350 (1938) ; Sipuel v. Board of Regents, 332 U. S. 631 (1948).

18. As applied to common carriers the rule of equal service is well settled. Missouri Pacific Ry. Co. v. Larabee Mills, 211 U. S. 612 (1909) (whereas no one can be compelled to engage in the business of a common carrier, if he does so, he becomes subject to duties imposed on common carriers to treat all alike).

19. "The federal policy reflected in Acts of Congress indeed bars [exclusion]. . . . [T] not see how approval of Mlichigan's law in any way interferes with the uniformity es- 
nically foreign character of the commerce in itself conclusive and argued that the burden arose merely from the state's acting outside its proper sphere. ${ }^{20}$

The disparate emphases of the concurring and dissenting opinions assume their primary significance when directed to state proscription of segregation, rather than exclusion. Since most interstate commerce is subject to the Interstate Commerce Act's ban on exclusion, the state acts are of limited importance where the charge is exclusion. But the civil rights acts which have been enacted in eighteen states forbid not only exclusion but segregation, ${ }^{21}$ and since no federal statute specifies a carrier's conduct in this regard, ${ }^{22}$ the application of the state act would depend on the concept of an unconstitutional burden on interstate and foreign commerce then adopted.

Determination of the ultimate criterion of burden would in turn depend upon the interpretation which the Court chose to attach to its holding in the recent case of Morgan $v$. Virginia. ${ }^{23}$ To preclude the possibility of con-

sential for the movement of vehicles in [interstate] commerce." Bob-Lo Excursion Co. v. Michigan, 333 U. S. 28, 42 (1948).

20. Id at $43-45$.

21. Today, seventeen states besides Michigan, see note 12 supra, prohibit as a discriminatory practice any difference in treatment based on race. CAt. CIv. CodE, $\$ \$ 51,52$ (Deering, 1937) ; Colo. Stat. c. 35, \$\$1, 8 (1935); Conn. Gen. Stat., \$1676c (Cum. Supp., 1935); Ill. Rev. Stat., c. 38, \&125 (Smith-Hurd, 1941); INd. Stat. ANN., \& 10 901 (Burns, 1933); Iowa Code, §735.1 (1946); Kan. Gen. Stat. ANn., \&21-2424 (1935) ; Mass. LAws, c. $272, \$ 98$ (Michie, 1933); Minn. STAT., \$ 7321 (Mason, 1927); Neb. Rev. Stat., c. 20-101 (1943) ; N. J. Stat. ANn., $10: 1-2,3,5$ (1939) ; N. Y. Consol. Laws, $\$ 40$ (Baldwin, 1933) ; Orio Gen. Code, 12940 (Page, 1937) ; Pa. Stat, tit. 18, $\$ \S 4653,4654$ (Purdon, 1930) ; R. I. GeN. Laws, c. 606, $\$ 28$ (1938); WASH. REv. STAT., $\$ 2686$ (statute does not specifically mention public conveyances, but is phrased in broatd, general language) (Remington, 1932) ; Wis. Stat., \$340.75 (1941). See Konvitz, TuE Constitution and Civil Rights 123-29 (1947).

These statutes were enacted by the states to fill the void left by the demise of federal legislation. Civil Rights Cases, 109 U. S. 3 (1883) (federal Civil Rights Acts, 14 Stat. L. 27 (1866), 16 Stat. L. 140 (1870), 18 Stat. L. 335 (1875), directed against individual discriminatory conduct, as distinguished from state action, held unconstitutional). See gcnerally Konvitz, op. cit. supra c. 2. Their constitutionality insofar as they apply to intrastate commerce has been clearly established. Greenberg v. Western Turf Ass'n, 204 U. S. 359 (1907) ; People v. King, 110 N. Y. 418 (1888). See also cases collected in Note, 49 A. L. R. 505.

22. Under the anti-discriminatory provisions of the Interstate Commerce Act, note 10 supra, segregation has been held permissible. Edwards v. Nashville, C. \& St. L. Ry, Co., 12 I. C. C. 247 (1907). But cf., Harlan, J., dissenting, Plessy v, Ferguson, 163 U. S. 537,559 (1896), to the effect that although segregation laws may not be subject to the charge of discrimination, the purpose behind them contradicts the fundamental concept that ". . . our Constitution is color blind and neither knows nor tolerates classes among its citizens". Cf. Edwards v. California, 314 U. S. 160 (1941) (statute prohibiting incligents from entering state-'Okie' law-invalidated as a denial of fundamental freedom of movement).

23. 328 U. S. 373 (1946). 
flicting state regulations, ${ }^{24}$ the Court here nullified a Virginia statute imposing racial segregation requirements upon interstate carriers while within the state. ${ }^{25}$ In so holding, it revived and strongly reiterated the rationale of Hall ข. DeCuir ${ }^{26}$ in which the Court, similarly faced with the problem of diverse and conflicting state regulation of national commerce, had invalidated a Louisiana anti-segregation requirement ${ }^{27}$ as enforced against interstate carriers.

At least superficially, the reliance of the Court in the Morgan case on the Hall rationale sets up the flat rule that a state may neither require nor forbid segregation in interstate commerce. It is a negative concept of uniformity, in that what is achieved is the absence of regulation. Apparently it is this kind of uniformity which Mr. Justice Jackson, from the language of his dissent in the Bob-Lo case, would require.

But in the minds of at least some of the Justices, the Morgan case may import more than it says. Its predecessor, the Hall opinion, was in its time not allowed its full possible effect, for shortly after the decision, state statutes requiring interstate carriers to employ Jim Crow cars within state borders were upheld.2s The state courts' construction of the statutes was that the required segregation applied only to intrastate passengers, and that there was therefore no burden on interstate commerce. ${ }^{3}$ The end actually furthered by the Court was that of segregation.

The Court in the Morgan case, aided by the explicit statement of the lower court that the Virginia statute was intended to apply to interstate commerce, ${ }^{30}$ clearly reversed the trend, and in so doing conformed it to currently widespread notions of racial equality. Today, both on the Court and off, new inroads are constantly being made on the institution of segrega-

24. "A burden may arise from a state statute which requires interstate passengers to order their movements on the vehicle in accordance with local rather than national requirements." Id. at 380, 381.

25. Vikginia Cove of 1942, $\$ \$ 4097$ - -4097 dd, Acts of Assembly, Virginia, 1930, p. $343-4$.

26. 95 U. S. 485 (1877).

27. La. Rev. Stat. 1870, p. 93.

28. Louisville, N. O. \& T. Ry. Co. v. Mississippi, 133 U. S. 587 (1890); Chesapealie \& O. Ry. Co. v. Kentucky, 179 U. S. 388 (1900); and cases collected in Notes, 30 A. L. R. 55,165 A. L. R. 589.

29. The construction of the segregation statute by the highest court of the state was held to be the conclusive determinant of its intrastate nature. Louisville, N. O. \& T. Ry. Co. v. Mississippi, 133 U. S. 587 (1890). In MicCabe v. Atchinsan, T. \& S. F. Ry. Co., 235 U. S. 151 (1914), the Court indicated in dictum that in the absence of state court construction, the statute would be construed as having been intended to have only intrastate application, on the assumption that the state legislature would not pass a law subject to invalidation. $I d$. at 160

Harlan, J., dissenting in Louisville, N. O. \& T. Ry. Co. v. Mississippi, sulgr, how:ever, considered the decision inconsistent with the Hall case. Id. at 592. And in Chesapeake \& O. Ry. Co. v. Kentucky, 179 U. S. $38 S$ (1900), he dissented without opinion.

30. "[T]he statute embraces all motor vehicles and all passengers, both interstate and intrastate" Morgan v. Virginia, 184 Va. 24, 37, 34 S. E. 2d 491, 496 (1945). 
tion. ${ }^{31}$ The Morgan case is but another in the series. Thus the Morgan case may in time be interpreted as recognizing a developing national policy against segregation, the policy itself, rather than the absence of policy pro* viding the basis of the uniformity required by the Commerce Clause.

If the Court were required to circumvent the Morgan rationale rather than invalidate eighteen Civil Rights Acts ${ }^{32}$ in their application to interstate and foreign commerce, it might well choose this means to do so. Justices Black and Rutledge, who concurred in the result in the Morgan case, would presumably vote to sustain the statutes. While Mr. Justice Douglas was in the majority in the Morgan case, his insistence on basing his decision in the Bob-La case on evidences of national policy ${ }^{34}$ suggests that he too might concur. And enough of the remaining Justices to constitute a majority might well limit the rationale of the Morgan case, when faced with the prospect of striking down the civil rights statutes of eighteen states. ${ }^{36}$

The legal effect of such a decision would be to leave untouched the doctrine of national uniformity as a test of burden on interstate and forcign commerce while repudiating the result of Hall $v$. DeCuir. Its practical effect would be merely to permit those states in which segregation is not practised to prohibit segregation in matters touching interstate and foreign commerce. But the decision would further define a national policy against segregation and thus help pave the way for its eventual elimination.

31. The courts have helped to shape this general development in recent decisions. Exclusion of Negroes from grand juries has been held contrary to the Fourteenth Amendment. Smith v. Texas, 311 U. S. 128 (1940). Exclusion of Negroes from primaries was held violative of the Fifteenth Amendment. Smith v. Allwright, 321 U. S. 649 (1943). Racial restrictive covenants will not be enforced by federal courts as violative of the Fourteenth Amendment. Shelby v. Kraemer, 334 U. S. 1 (1948). See generally, KowvirZ, op. cit. sipra note 21, 109-132; Mangum, The Legai Status of tie Negro (1940), c. 3; and Waite, The Negro in the Supreme Coutr, 30 MINN. L. Rev. 219 (1946).

That a powerful undercurrent of prejudice and fear still prevents federal civil rights legislation is of course painfully obvious, and well evidenced by the reception accorded tho President's civil rights program by certain groups and the subsequent formation of the States' Rights Party. N. Y. Times, Jul. 18, 1948, p. 1, col. 1. It may be noted, however, that the program was as ambitious as any yet attempted in the civil rights field. Sce the Report of the President's Committee on Civil Rights, To Secure These Riguts (1947). And while an end to segregation in the military services and federal jobs, long sought by Negro groups, see N. Y. Times, Apr. 1, 1948, p. 1, col. 2, is still unattained, decisive steps have been taken in this direction with the establishment of the President's Committee on Equality of Treatment and Opportunity in the Armed Services, and the Fair Employment Board composed of members of the Civil Service Commission. Sce N. Y. Times, July 28, 1948, p. 1, col. 8. Legislation has aided Negroes in certain other fields. 48 Stat. 1185 (1934), 45 U. S. C. 151 et seq. (1946) (collective bargaining agents must represent all employees in the bargaining unit without discrimination becauso of race). Steel v. Louisville \& N. Ry. Co., 323 U. S. 192 (1944); Tunstall v. Brotherhood, 323 U. S. 210 (1944).

32. See note 21 supra.

33. Morgan v. Virginia, 328 U. S. 373, 386 (1946).

34. See note 19 supra.

35. But see Burton, J., dissenting, Miorgan v. Virginia, 328 U. S. 373, 389-394 (1946), on the ground that invalidation of the Virginia statute as applied would compel invalida- 